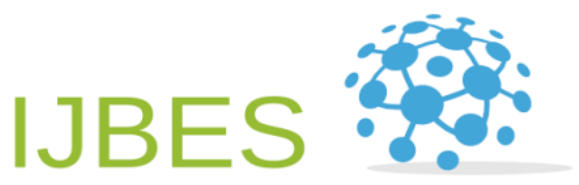

Business Ecosystem \& Strategy

IJBES VOL 3 NO 1 ISSN: 2687-2293

\title{
Role of foreign direct investment in banking sector and their impact on employment: Kosovo case
}

\author{
Sokol Krasniqi (a) (iD Ismail Mehmeti ${ }^{(b) *}$ \\ ${ }^{(a, b)}$ University of Applied Sciences in Ferizaj, 30000 Ferizaj- Kosovo
}

\author{
ARTICLE INFO \\ Article history: \\ Received 08 September 2021 \\ Received in rev. form 29 Sept. 2021 \\ Accepted 05 November 2021 \\ Keywords: \\ FDI, Banking System, Employment, \\ Economic Development \\ JEL Classification: \\ O19, O23, P45
}

\begin{abstract}
A B S T R A C T
The purpose is to identify the role and importance of Foreign Direct Investment (FDI) for the Kosovo economy, emphasizing FDI in the banking sector and their impact on employment growth - comparing FDI levels with countries of the Western Balkans. Data processing design is in line with a focus on data published by local and international organizations and institutions, using methods deductive, comparing research data synthetically and analytically with direct access to literature, scientific journals, official reports published domestically and abroad. Kosovo aims to regulate favorable legal infrastructure by attracting as much FDI as possible to other countries in the region. In this context, in Kosovo the economic field is regulated by legal provisions covering the area of FDI, which is very favorable compared to other Western Balkan countries. This paper provides sufficient data to show the current state of FDI in Kosovo compared to the countries of the Balkan region, as well as the extent to which FDI has affected employment growth in the Kosovo banking sector. The practical implication also relates to identifying the improvement of positive legal conditions for more FDI attraction. The data in the paper present the real situation of FDI in Kosovo and their role in economic development, emphasizing the country's banking sector and how Kosovo stands for FDI relative to the Western Balkan countries.
\end{abstract}

\section{Introduction}

In the global economy, different countries pay a great deal of attention to foreign direct investment, as these investments play a key role in economic development. Among the main advantages of FDI can be mentioned technology transfer, promotion of competition in the country, creation of new jobs, growth of host countries etc.

Most host governments have changed their perceptions of FDI. They try to promote as much FDI in certain industries as possible by promoting policies that help their countries economically and socially. Political stability, favorable business climate, and improved infrastructure are some of the incentive policies pursued by host country governments to absorb a significant number of FDIs.

Initially FDI orientation was mainly in manufacturing but now their diversification is also happening in services. Although some services such as: data processing or software programs are more service oriented in the domestic market than in the foreign markets. This has also happened as a result of the privatization of state-owned service companies such as telecommunications, transport, energy and finance, Nunnenkamp, Peter (2002).

The main motives that encourage foreign investors to invest in their host countries are:

\footnotetext{
i. $\quad$ Market size and growth prospects;

ii. Wage level and labor productivity;

iii. Good infrastructure;
}

* Corresponding author. ORCID ID:

(C) 2021 by the authors. Hosting by Bussecon International Academy. Peer review under responsibility of Bussecon International Academy.

http://dx.doi.org/10.36096/ijbes.v3i1.241 
iv. Political stability and measures to promote FDI;

v. Lack of corruption and promotion of competitiveness among firms;

Improving the investment environment, such as: business registration, licensing procedures, ease of doing business, business-friendly environment etc. Even the tax structure can have a significant impact on investment prospects. Chakrabati, A. (2001).

Approval of the Law on Foreign Investment in Kosovo December 2013 (Law No. 04/2013) provides equal treatment for foreign and domestic investors by offering:

i. Non-discriminatory treatment

ii. Continuous protection and security

iii. Compensation in case of nationalization or expropriation, including interest payment

iv. Compensation in case of violations of applicable laws and international law on Kosovo

v. Free transfer as well as unlimited use of income

vi. Protection against retroactive application of laws

Also, investments in new sectors can stimulate the development of new 'know how' infrastructure and technologies, technologies in the country where they are realized, while at the same time increasing professional, management and technical capacity of the EU for candidate countries (as well as for Kosovo) puts the emphasis on improving the business development environment.

The existence of a stimulating legal framework for foreign direct investment, increased levels of security for investing, improved physical infrastructure, reduced administrative barriers, qualified workforce indicate improved climate and greater opportunities to invest in the country.

The main barriers identified are:

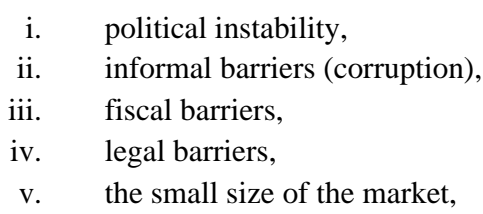

\section{Literature review}

Foreign direct investment also affects the job market through the creation of new jobs. Among the most significant and long-term impacts of FDI is the transfer of technology and know-how embodied in human capital. If foreign investment is undertaken in activities where local firms have limited experience, then FDI will influence the transfer of important knowledge in terms of training, management practices and techniques, and organizational behavior. FDI can also increase productivity through research and development (R\&D) by positively affecting the output of Campos and Kinoshita (2002) Foreign Direct Investment as Technology Transferred: Some Panel Evidence from the Transition Economies.

But foreign investment, on the other hand, also requires the provision of adequate human resources and a normal infrastructure, especially in attracting serious investment. In general, foreign investment, where generating and expanding businesses, can help hire, raise salaries, or replace critical or declining market sectors. However, not infrequently, the benefits of these investments can only be felt by a very small segment of the population, such as when the relevant employment, qualification and training is limited to a very small group of well-educated elites, ie and in relatively better condition, or even when some urban investment uses a pronounced "differentiator", even in some cases as deep pay discrimination.

At the same time, the role and impact of FDI in human capital development should be emphasized. The education and training system needs to be upgraded in order to comply with the requirements of foreign investors for new hires. In addition, FDI can be transformed into employment opportunities, greater local competitiveness and penetration of local producers into foreign markets.

The development of economic policies in Kosovo which came into force in 2009 have increased FDI in countries. The resumption of the privatization process, and the reduction of corporate tax, can be singled out as more positive developments.

Table 1: Corporate Income Tax Rate in Kosovo

\begin{tabular}{cc}
\hline Corporate Income Tax & \\
\hline Until 2008 & From 2009 \\
\hline $20 \%$ & $\mathbf{1 0 \%}$ \\
\hline
\end{tabular}

Source: Law no. 03 / L-113, corporate tax rate 
Also, Kosovo's membership in international institutions in 2009 such as: The International Monetary Fund (IMF) and the World Bank (WB) are a positive impetus for potential investors. The increase in FDI has also contributed to the increase in investment in the road infrastructure sector.

The membership of the Republic of Kosovo in the EBRD (December 2012) has assisted in economic development, implementation of European reforms and standards and infrastructure development by supporting the development of the private sector, mobilizing external capital and improving the investment environment.

Table 2: FDI in Kosovo 2010 - 2020 (in mil. euro)

\begin{tabular}{|c|c|c|c|c|c|c|c|c|c|c|c|}
\hline Viti & 2010 & 2011 & 2012 & 2013 & 2014 & 2015 & 2016 & 2017 & 2018 & 2019 & 2020 \\
\hline IHD & 368.5 & 384.4 & 229.1 & 280.2 & 151.2 & 308.8 & 220.0 & 255.4 & 213.70 & 271.80 & 341.70 \\
\hline
\end{tabular}

Source: Central Bank of Kosovo 2021 (CBK)

In Kosovo, FDI remains largely concentrated in sectors of the economy such as real estate, renting and other business activities, commercial services and financial services. Higher FDI growth was recorded in the financial services and construction sector (32.6 and 22.6 million euros more than in the same period last year), while the trade sector was characterized by a decline of 7.4 percent.

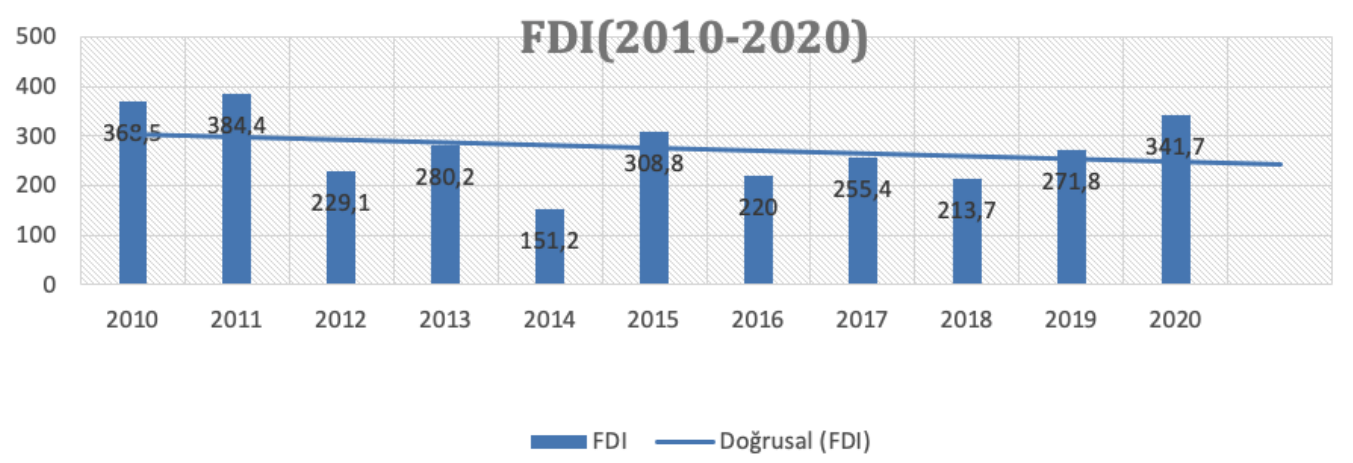

Figure 1: FDI report in Kosovo presented in a linear fashion; Source: 2021 Annual Report - CBK

Southeast European countries attracted a significant number of foreign direct investment thanks to the good business climate, lower labor costs, ease of access to European markets and, mainly, the privatization of state-owned enterprises.

In its investment report, UNCTAD, puts Southeast European countries in the group of transition countries. Foreign direct investment increased last year in Southeast Europe by 34 per cent to 6.7 billion euros. Serbia has been the biggest attractor of foreign direct investment by 2,870 m euros, decreasing it by 12.88 per cent on last year. In Albania, direct investment was 940 million euros, down slightly from a year earlier for 11.47 percent. In Northern Macedonia, investments havereduced from 13.58 percent reaching $240 \mathrm{~m}$ euros. The country with the better foreign direct investment in Southeast Europe for 2020 is Kosovo with 341.7 million euros with increase of 12.57 percent, Bosnia and Herzegovina with 347 million euros. Montenegro had $663 \mathrm{~m}$ euros in foreign direct investment, 11.23 percent less than a year ago.

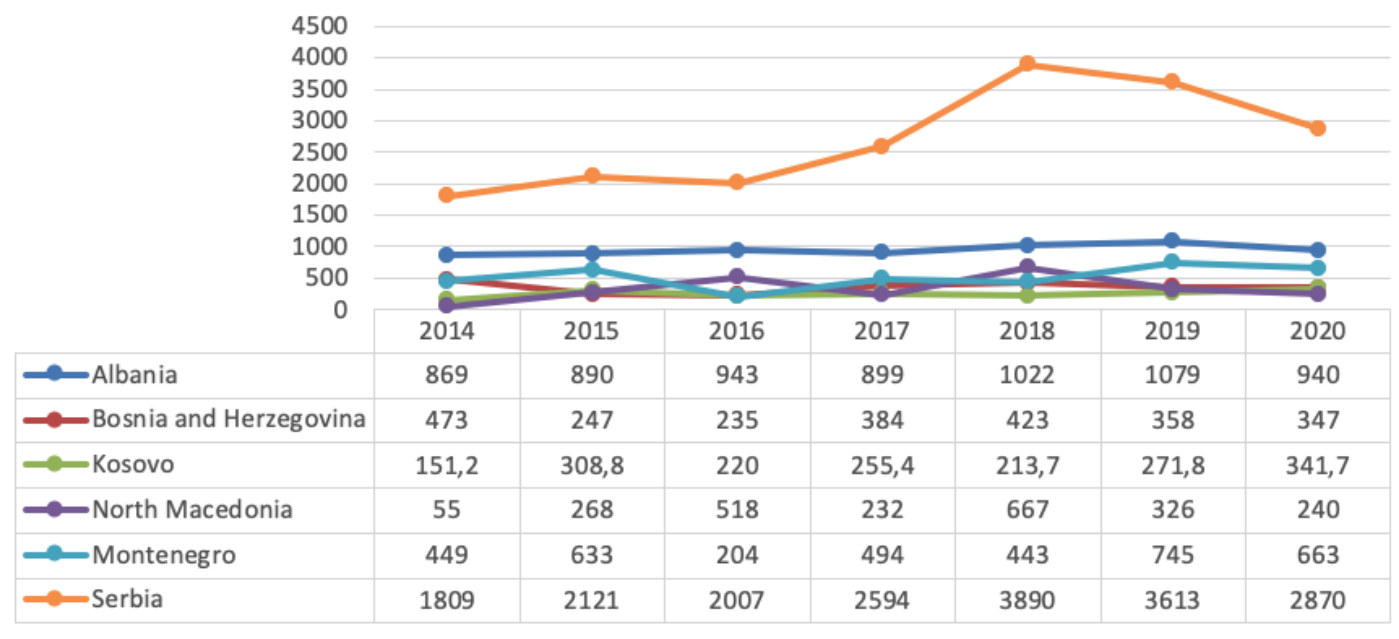

Figure 2: Report on FDI in Kosovo and Western Balkan Countries in mil. Euro; Source: Authors 
During the period 2017-2020, Kosovo recorded the highest employment growth during this period (8.5 percent). Although the unemployment rate declined across the region, it still remains high, especially in Kosovo at 25.6 percent. The youth unemployment rate is a major concern: more than half of Kosovo's youth are unemployed, while its level in Albania reached the lowest rate of 26.4 percent (World Bank.2020).

$\operatorname{FDI}(2010-2020)$

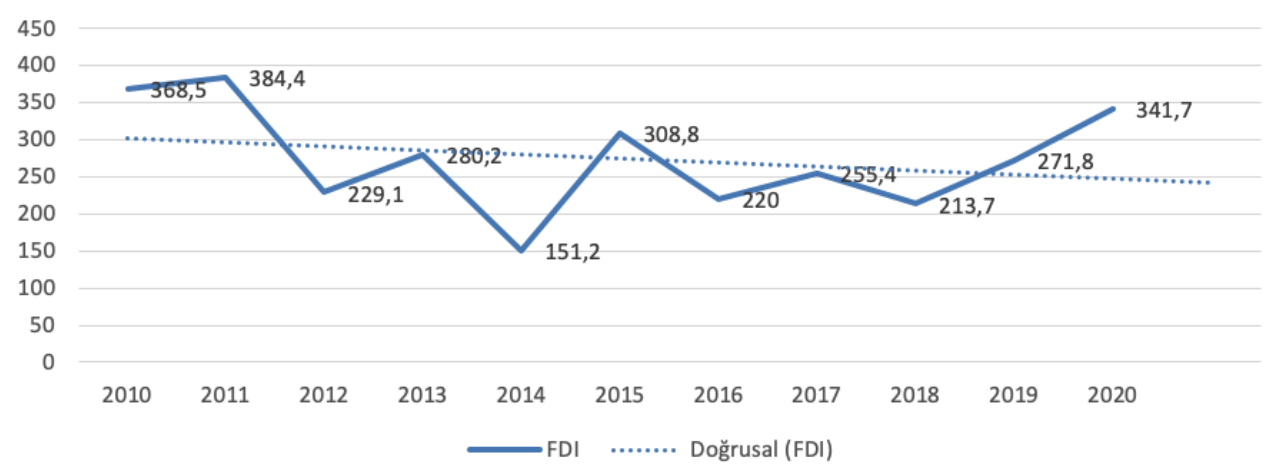

Figure 3: Graph of Foreign Direct Investment (2010-2020) in Kosovo; Source: Authors

The main origins of FDI inflows continue to be: Germany, Switzerland and Austria, partly due to the Kosovar diaspora in these countries. Implementation of the SAA, recent improvements in the business environment and stronger growth of the Eurozone continue to support FDI inflows and remittances.

\section{Research and Methodology}

Data processing design (on the role and importance of FDI in a country's economy) is in line with established international standards with a focus on data published by local and international organizations and institutions, using methods deductive, comparing research data synthetically and analytically with direct access to literature, scientific journals, official reports published domestically and abroad.

\section{Empirical data and analysis}

Foreign Direct Investment in the Kosovo Banking System-Commercial banks in Kosovo have been operating since the end of 1999. Even before the war in Kosovo, various banks operated but they were of an outdated economic and political system. Commercial banks or commercial banks carry out their business in accordance with the law on banks and therefore the Central Bank of Kosovo $(\mathrm{CBK})$ is responsible for licensing banks.

Kosovo's banking sector is the youngest in the region and Europe, with 11 commercial banks, with over 90.50\% foreign working capital, and the Central Bank of Kosovo, which became operational in 2008. Its journey begins in a state of flux, where Kosovo's economy was in an emergency survival phase, and continues to remain stable, despite Kosovo's economic situation.

Despite the usual challenges and circumstances and those of the pandemic Covid 19, with the measures and actions taken during 2020, it has been achieved that the financial sector is kept stable, stable and competitive, as well as with an upward trend in all its components (capital, liquidity, lending, deposits, financial actors, financial products and services, and users of financial services).

These developments have enabled the efficient support of the country's economy by the financial sector, continuous reduction of the cost of financial intermediation, increase of citizens' trust in the financial sector and increase of the interest of foreign investors in this sector.

Kosovo's banking sector constitutes as Kosovo's largest financial sector. Banking sector assets in 2020 recorded an annual growth of 12.50 percent, reaching a value of euro 5.35 billion, despite the uncertainties brought by the restriction of economic activities, the assets of banking sector marked a slower growth compared to the previous year, which is mainly attributed to the performance with which the lending activity was characterized, CBK (2021).

There are eleven (11) banks that are operating nowadays in the banking system in Kosovo, representing 67.8 percent of the total assets in the financial sector. Their products and services include banking accounts, loans, domestic and international payments, banking cards, banking guarantees, letter of credit, e-banking. Access to these services is enabled through 211 branches and subbranches, 513 ATMs, 13,175 POS, and 411,347 e-banking accounts, CBK (2021).

If we compare the number of commercial banks in Kosovo and the region then based on statistics from the Central Banks of these countries Kosovo still has the smallest number, while countries such as: Albania which has 12 commercial banks, Macedonia 15 banks commercial banks, Serbia has 27 commercial banks, Montenegro has 13 commercial banks and Bosnia and Herzegovina 23 commercial banks. 
The banking sector capital structure continues to be dominated by foreign capital, where at the end of 2018, eight (8) out of ten (10) licensed banks operating in the country are foreign-owned and account for $90.2 \%$ of total equity capital. The most attractive investment sector to date has been that of banks, mainly equity from Austria (Raiffesen Bank), Germany, the Netherlands (Pro Credit Bank), Italy, Switzerland, Liechtenstein, and the EBRD (BpB) ${ }^{1}$, Slovenia's capital. (NLBanka) created by the merger of BRK and Kasabank $^{2}$, most recently Turkish capital (BTK, TEB \& BNP Paribas - Turkey \& France) ${ }^{3}$ iŞ Bankasi ${ }^{4}$, Ziraat Bankasi ${ }^{5}$,CREDINS Bank $^{6}$ as well as some international financial institutions. Whereas, the insurance sector has attracted investment from Albania, Croatia and the Kosovar diaspora. A World Bank study shows that a market economy legislation has been created in Kosovo, but the main problem lies in the operational level where his.

The Banking and Insurance sectors were among the most attractive sectors for foreign investment in Kosovo. These sectors have absorbed $€ 30.6$ million, of which 19.3 (63\%) is the share of foreign capital comprising $€ 13$ million of the banking sector and $€ 6.3$ millions of insurance.

Compared to most other countries in the Region, Kosovo's banking system is characterized by several positive features:

i. Possesses a deposit-based financing structure (the ratio of loans to deposits was 81.90 percent at the end of 2020);

ii. It is well capitalized (capital adequacy stands at 17.40 percent, minimum required is 12.0 percent at the end of 2020) and has plenty of liquidity protection, without relying on external financing although dominated by foreign owned banks (accounting for about 90 per cent of all banking assets, with the two largest German banks ProCredit and Austrian Raiffeisen, each with 26 per cent market share).

iii. Sector loan portfolio banking sector expanded by 7.1 percent, while the value of total loans reached 3.25 billion euros in year 2020. Growth dynamics during this year turns out to be slower compared to double-digit increases of the last four years. In the same period, deposits in the banking sector of Kosovo reached the value of 4.36 billion euros and marked an annual increase of 11.6 percent (16.2 percent in 2019).

iv. The non-performing loan rate changed the downward trend it had in the last six years, rising to 2.7 percent in December 2020 , from an all-time low of 2.0 percent since marked the end of 2019. The increase is initially attributed to the methodological change of the assessment of CBK Annual Report 2020 credit risk, where the non-performing loan rate rose to 2.5 percent in February 2020. Following, the increase in non-performing loans reflects the increased risk posed by the pandemic situation. The level in coverage of non-performing loans with provisions in this period was 139.6 percent from 163.5 in the previous year, CBK Annual Report, (2021).

v. Profitability indicators continue to be stable. Return on Average Assets (RAA) and Return on Average Equity (RAE) were 2.5 percent and 20.4 percent, respectively.

Table 3: Structure of Commercial Banks

\begin{tabular}{ll}
\hline Commercial Banks & \\
\hline Number of banks & 11 \\
\hline Foreign owned banks & 9 \\
\hline Number of units & 211 \\
\hline Concentration rate & $61.4 \%$ \\
\hline Foreign ownership & $88.3 \%$ \\
\hline Number of Employees & 3,391 \\
\hline
\end{tabular}

Source: 2021 Annual Report - CBK

During the years of research, there has been a decrease in branch outreach in 2020 to 211 branches and a reduction in staff in 2020 of 3,391 and as a result of the expansion of automated services such as e-banking, ATMs, sales terminals, mobile banking etc.

Table 4: Report between bank branches and banking sector employee

\begin{tabular}{lllllllllllll}
\hline Year & $\mathbf{2 0 0 9}$ & $\mathbf{2 0 1 0}$ & $\mathbf{2 0 1 1}$ & $\mathbf{2 0 1 2}$ & $\mathbf{2 0 1 3}$ & $\mathbf{2 0 1 4}$ & $\mathbf{2 0 1 5}$ & $\mathbf{2 0 1 6}$ & $\mathbf{2 0 1 7}$ & $\mathbf{2 0 1 8}$ & $\mathbf{2 0 1 9}$ & $\mathbf{2 0 2 0}$ \\
\hline Branch & 295 & 311 & 310 & 310 & 298 & 277 & 265 & 262 & 238 & 222 & 217 & 211 \\
\hline Employers & 3,459 & 3,610 & 3,728 & 3,722 & 3,549 & 3,507 & 3,375 & 3,375 & 3,319 & 3,255 & 3,303 & 3,391 \\
\hline
\end{tabular}

Source: 2021 Annual Report - CBK (edited by the authors)

\footnotetext{
${ }^{1}$ The EBRD has been a shareholder in BpB since 2011 with $10 \%$ of the Bank's total capital

${ }^{2}$ NLB BRK and NLB Kasabank from 01.01.2008 have been integrated into a bank "NLB Prishtina" (approved by CBAK on 18.12.2007).

3. TEB Bank (Turkish Economy Bankasi) joint venture with BNP Paribas, obtained full license from CBAK (now CBK) on 18.12.2007.

${ }^{4}$ Turk IS Bankasi A.S. is the largest Turkish bank, which entered the Kosovo market under a CBK license in November 2012

${ }^{5}$ Ziraat Bankasi - founded in June 2015. Ziraat Bankasi, or Bank of Agriculture, is one of the three Turkish public banks, established nearly 150 years ago

${ }^{6}$ CREDINS Bank Kosova - founded in 2020, is one of the three bigest bank in Albania
} 
Having the youngest population in Europe for Kosovo can be a competitive advantage in terms of labor supply and availability of human capital,

In most of these studies, human capital is listed as a very important, and sometimes important, determinant in the process of attracting FDI and increasing the level of FDI inflows.

To assess the impact of Foreign Direct Investment in Kosovo on the banking sector, research questions were formulated that PH1: Did foreign direct investment affect banking sector employment and research question PH2: How does business environment change affect growth? FDI

The main questionnaire questions that will help in verifying PH1 are: P1, P2, and P4 questionnaire dedicated to the banking sector employees, derived from the Likert scale formulation.

Table 5: Reviews on the impact of FDI on employment in the banking sector

\begin{tabular}{|c|c|c|c|}
\hline & Formulations & Employees in the ba & king sector \\
\hline & & Level of compliance & Interpretation \\
\hline RQ1\Q1 & $\begin{array}{l}\text { Main reasons that influence FDI companies' decision to invest } \\
\text { in Kosovo }\end{array}$ & $>4$ & Subscribe \\
\hline RQ1\Q2 & $\begin{array}{l}\text { Assessing the availability and quality of human capital in } \\
\text { Kosovo }\end{array}$ & $>4$ & Subscribe \\
\hline
\end{tabular}

Source: Authors

To carry out this study, the questionnaire was distributed electronically and personally "face to face" to senior management and bank managers in Kosovo. There were also direct interviews with managers of some banks. To assess the problematic of investment in the banking sector, 3 assertions were used (Spaho, 2011; Lin and Li, 2006), on a 5-point Likert scale, with 1 indicating 'strongly disagree' and 5 'strongly agree'. Cronbach's alpha coefficient was calculated to test the reliability of the data on the Likert scale.

Responses were coded prior to their processing in SPSS, after the data coding process, the next step was to transform the coded data from Excel into SPSS. Data analysis and processing were done through SPSS 16.0 statistical processing software (Sandalowski, Voilse and Knafl, 2009) (Trochim, 2006). Through different forms of reporting and examining different variables.

The 'employment growth' variable has a value of 1 if the sum of the values of the 3 variables on the Likert scale above is greater than the corresponding mean of the whole choice and 0 otherwise. The Cronbach's alpha coefficient value of this variable was 0.802 .For our degree of reliability we find the Cronbach's alpha coefficient value to be (Cronbach's Alpha 0.802) for the 10 questions asked.

\section{Results and discussion}

Descriptive analysis - Of the 8 (eight) banks surveyed in the study, data were found showing that the total investment made by foreign and domestic banks in Kosovo is as follows: one bank invested less than $€ 1$ million, two banks invested 1-10 mil. euros, three banks invested 50-100 mil. euros and one bank over 100m euros.

While in terms of years of operation in Kosovo, the first commercial bank started operating in Kosovo in 2000, then in 2001 two more commercial banks were opened, continuing until 2015 when the last bank that started operating in Kosovo.

Table 6: Regression of dependent variables

\begin{tabular}{lllll}
\hline \multicolumn{2}{l}{ Model Summary } & & & \\
\hline Model & $\mathrm{R}$ & R Square & Adjusted R Square & Std. Error of the Estimate \\
\hline $\mathbf{1}$ & $.649^{\mathrm{a}}$ & .421 & .389 & 1.227 \\
\hline
\end{tabular}

a. Predictors: (Constant), PH1.1, PH 1.2

Source: Authors

The major changes in education recommended by FDI companies to make human capital more appropriate to their need is decisive in increasing FDI in the banking sector with independent variables

The Model Summary gives the R values for evaluating the overall fit of the model. The adjusted R-square value in this case is (.421). This tells us that the two independent variables in our model accounted for 42.10 percent of the variance in the model-dependent performance variable. 
Table 7: Results of ANOVA regression for banking sector employee growth as a result of FDI growth in this sector

\begin{tabular}{|c|c|c|c|c|c|c|}
\hline \multicolumn{7}{|c|}{ ANOVA $^{b}$} \\
\hline Model & & Sum of Squares & df & Mean Square & $\mathbf{F}$ & Sig. \\
\hline \multirow[t]{3}{*}{1} & Regression & 39.374 & 2 & 19.687 & 13.073 & $.000^{\mathrm{a}}$ \\
\hline & Residual & 54.216 & 36 & 1.506 & & \\
\hline & Total & 93.590 & 38 & & & \\
\hline $\begin{array}{l}a . \\
b .\end{array}$ & \multicolumn{5}{|c|}{ Predictors: (Constant), PH1.1, PH1.2 } & \\
\hline
\end{tabular}

Source: Authors

Anova or analysis of variance was used to compare the averages of the two populations, revealing the main effects of the interaction of the independent variables on more dependent variables

Table 8: Regression results for the growth of banking sector employees as a result of FDI growth in this sector, Coefficients ${ }^{\mathrm{a}}$

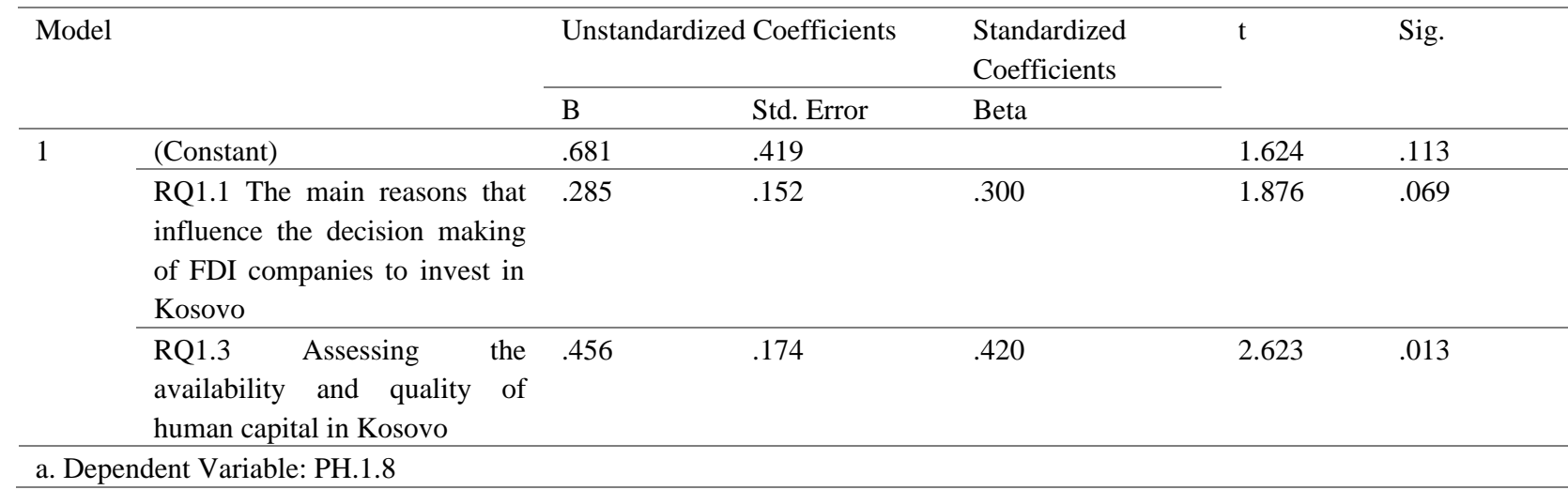

Source: Authors

From this logistic regression we conclude that the variable: "The main reasons that influence the decision making of FDI companies to invest in Kosovo" is significant (significance level .069) with the dependent variable being in this case that the increase of banking sector employees through FDI. Elimination of corruption indicates that it depends on the dependent variable (significance level .021). and Assessment of the availability and quality of human capital in Kosovo (significance level .013).

Table 9: Reviews of thinking on improving the business environment in increasing FDI

\begin{tabular}{|c|c|c|c|}
\hline \multirow[t]{2}{*}{ Question } & \multirow[t]{2}{*}{ Formulations } & \multicolumn{2}{|c|}{ Employees in the banking sector } \\
\hline & & $\begin{array}{l}\text { Level of } \\
\text { compliance }\end{array}$ & Inteprettation \\
\hline RQ2\Q7 & $\begin{array}{l}\text { Improving Kosovo's education system increases FDI } \\
\text { interest }\end{array}$ & $>4$ & subscribe \\
\hline RQ2।Q9 & $\begin{array}{l}\text { How do you assess the business climate in Kosovo in } \\
\text { terms of FDI }\end{array}$ & $>4$ & subscribe \\
\hline RQ21Q10 & Eliminate Corruption & $\leq 3$ & inconclusive \\
\hline
\end{tabular}

\section{Source: Authors}

Dependent Variable Regression The changing business environment influences the growth of FDI-independent variables.

Table 10: Dependent Variable Regression Improvement of the Doing Business Environment on FDI Growth-Independent Variables

\begin{tabular}{llll}
\hline \multicolumn{2}{l}{ Model Summary } \\
\hline $\mathbf{R}$ & R Square & Adjusted R Square & Std. Error of the Estimate \\
\hline $\mathbf{7 8 2}^{\mathbf{a}}$ & .611 & .575 & 1.043 \\
\hline
\end{tabular}

a. Predictors: (Constant), PH2.7, PH 2.9, PH 2.10

Source: Authors 
The Model Summary gives us the R values for evaluating the overall fit of the model. The adjusted R-square value in this case is (.575). This tells us that the two independent variables in our model account for $57.50 \%$ of the variance in the model-dependent performance variable

Table 11: ANOVA regression results for banking sector employees

\begin{tabular}{lllllll}
\hline \multicolumn{2}{l}{ ANOVA $^{\mathrm{b}}$} & \multicolumn{1}{c}{} & & & \\
\hline Model & & Sum of Squares & df & Mean Square & F & Sig. \\
\hline \multirow{1}{*}{} & Regression & 54.800 & 3 & 18.267 & 16.779 & $.000^{\mathrm{a}}$ \\
\cline { 2 - 6 } & Residual & 34.838 & 32 & 1.089 & & \\
\cline { 2 - 5 } & Total & 89.639 & 35 & & & \\
\hline
\end{tabular}

a. Predictors: (Constant), PH 2.7, PH2.9, PH 2.10

b. Dependent Variable: PH 2.6 (edited by the authors)

Source: Authors

From this logistic regression we conclude that the variable: "Improving the business environment affects FDI growth" is significant (significance level .002) with the dependent variable being in this case the increase in employees. in the banking sector through FDI. The elimination of corruption indicates that it depends on the dependent variable (significance level .021). and that improving the education system in Kosovo increases FDI interest (significance level .032).

Table 12: Regression results for banking sector employees

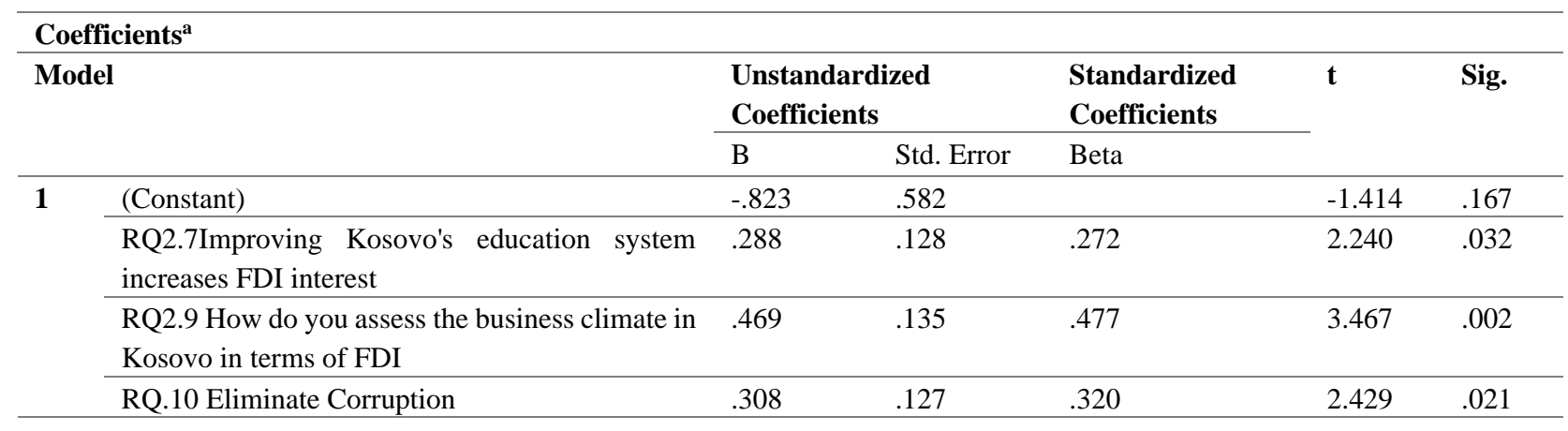

a. Dependent Variable: PH 2.6 (edited by the authors)

Source: Authors

Because the data are grouped into different categories and purposes, the data submission will not be presented in the order of the questionnaire questions. The more we look at the findings, the more accurate our findings will be. The variety of general data used in this research will only have a positive impact on the findings presented and on the research as a whole.

\section{Conclusions}

Given an improved business climate, a stable macroeconomic environment, large natural resources, and especially low labor costs, Kosovo can become an attractive place for foreign investors to do business. However, it should be noted that attracting FDI, in addition to monetary and fiscal incentives, must be accompanied by continued development and an increase in the level of human capital, as a prerequisite for attracting FDI. The World Bank report in 2018 ranked Kosovo among the top 10 economies worldwide that have seen the biggest improvement in doing business reforms. Kosovo ranks 57th out of 190 countries for 2020 in terms of ease of doing business, compared to 44th place it had a year ago, leaving behind Southeast European countries like Bulgaria (61), Greece (79), Albania (81), BiH (90). Kosovo can survive most of its neighboring countries when it comes to low labor costs and the simplicity of hiring new employees. With the average monthly labor cost estimated at $€ 519$, the main advantage of the labor force in attracting FDI remains the low cost. The relationship between new foreign investment, high unemployment, the functioning of the education system and the current level of human capital development is considered a very critical combination of Kosovo's economic development policies in the future. What kind of human capital and education system Kosovo is able to create can determine the future level and types of foreign investment.

Our main conclusion is that, in fact, human capital exerts a positive and significant impact on attracting FDI. The study provided a strong assessment of the value of human capital (before and after investments) by foreign investors investing in Kosovo. Of course, this is not to say that human capital is the sole determinant of investment. The study also revealed perception of corruption as a major 
obstacle to boosting foreign investment in the country. Many international and local organizations have previously identified this as an obstacle to progress.

The research showed that the perception of corruption is still widespread and remains a major concern for all Kosovo citizens. formal and business needs (relation: theory vs practice). We argue that an important development would be more access to staff training, which is cheaper and more efficient than trying to provide general university education at all levels, including those areas for which there is already satiety in the labor market. From the research we conclude that the opening of new specialized and vocational schools is one of the options.

Government and private initiatives have been taken to improve and reform the education system in Kosovo, but they may not be enough. The business environment in the Republic of Kosovo is becoming one of the most competitive in the region. The advantages created, such as a favorable tax system, abundant natural resources, fast and easy business registration, cheap labor force, transparent foreign investment laws and other advantages, make Kosovo an attractive and favorable environment. for foreign investors. Human capital ranks as a very important determinant in the process of attracting FDI and increasing the level of FDI inflows.Given this definition, human capital is considered among the most important capital for any economy. Human capital is the area where the transition process has had particularly important and long-term implications. Having the youngest population in Europe for Kosovo can be a competitive advantage in terms of labor market supply and availability of human capital, but reforms are needed ongoing in the education system.

\section{References}

Bevan, A. A., \& Estrin, S. (2000). The determinants of foreign direct investment in transition economies. Bevan, Alan A. and Estrin, Saul and Estrin, Saul, The Determinants of Foreign Direct Investment in Transition Economies (December 2000). Available at SSRN: https://ssrn.com/abstract=258070

Bora, B. (2000). Theodore H. Moran Foreign Direct Investment and Development. Asian Pacific Economic Literature, 14(2), 30-30.

Campos, N. F., \& Kinoshita, Y. (2002). Foreign direct investment as technology transferred: Some panel evidence from the transition economies. The Manchester School, 70(3), 398-419. https://doi.org/10.1111/1467-9957.00309

CBK (2019). Annual Report

Chakrabarti, A. (2001). The determinants of foreign direct investments: Sensitivity analyses of cross-country regressions. kyklos, 54(1), 89-114. https://doi.org/10.1111/1467-6435.00142

De Mello Jr, L. R. (1997). Foreign direct investment in developing countries and growth: A selective survey. The journal of development studies, 34(1), 1-34. https://doi.org/10.1080/00220389708422501

De Mello, L. R. (1999). Foreign direct investment-led growth: evidence from time series and panel data. Oxford economic papers, 51(1), 133-151. https://doi.org/10.1093/oep/51.1.133

Foreign Investment Law no.04 / 2013

Hannon, P., \& Reddy, S. (2012). China edges out US as top foreign investment draw amid world decline. Wall Street Journal, 1023.

Moosa, I. (2002). Foreign direct investment: theory, evidence and practice. Springer.

Nunnenkamp, P. (2002). Determinants of FDI in developing countries: has globalization changed the rules of the game? (No. 1122). Kiel working paper. https://www.econstor.eu/handle/10419/2797

Pitelis, C., \& Sugden, R. (Eds.). (2000). The nature of the transnational firm. Psychology Press.

Resmini, L. (2000). The European Bank for Reconstruction and Development 2000

Schneider, F., \& Frey, B. S. (1985). Economic and political determinants of foreign direct investment. World development, 13(2), 161-175.

Shenkar, (2007). FDI Theory and Application

Study Report (2014). Riinvest, Prishtina

UNCTAD, Annual FDI Report 2020

http://pubdocs.worldbank.org/en/502631475173890972/al-SEE-RER-n-10-KOS.pdf

http://www.oecd-ilibrary.org

http://www.riinvestinstitute.org

https://gzk.rks-gov.net

https://mti.rks-gov.net

https://www.bqk-kos.org

Publisher's Note: Bussecon International stays neutral with regard to jurisdictional claims in published maps and institutional affiliations.

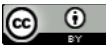

International Journal of Business Ecosystem and Strategy by Bussecon International Academy is licensed under a Creative Commons Attribution 4.0 International License. 